\title{
ANALISIS USAHATANI JAGUNG KUNING DAN KONTRIBUSINYA TERHADAP PENDAPATAN PETANI DI KECAMATAN BONTOLEMPANGAN KABUPATEN GOWA
}

\author{
Hardiyono*) \\ Dosen STIE AMKOP Makassar
}

\begin{abstract}
Abstrak
Usahatani jagung kuning di Kabupaten Gowa khususnya Kecamatan Bontolempangan merupakan satu komoditi yang berpotensi untuk dikembangkan dan dapat meningkatkan pendapatan petani. Penelitian ini diarahkan untuk mengetahui bagaimana usahatani jagung kuning dan konstribusinya terhadap pendapatan petani di Kecamatan Bontolempangan Kabupaten Gowa. Pendapatan petani jagung kuning sebesar Rp. 5.061.919,00 per hektar per musim tanam, dengan $\mathrm{R} / \mathrm{C}$ ratio sebesar 3,69 dan $\mathrm{B} / \mathrm{C}$ ratio 2,69 , dan margin yang diterima tiap-tiap saluran pemasaran berbeda-beda. Untuk saluran I pedagang pengumpul mendapatkan keuntungan sebesar Rp. 90/kg, margin pemasaran Rp. 150/kg. Pedagang besar mendapatkan keuntungan sebesar Rp. 130/kg, margin pemasaran Rp. 200/kg. Pedagang pengecer mendapatkan keuntungan sebesar Rp. 230/kg, margin pemasaran Rp. 300/kg. Untuk saluran II pedagang besar mendapatkan keuntungan sebesar Rp. 255/kg, margin pemasaran Rp. 350/kg. Pedagang pengecer mendapatkan keuntungan sebesar Rp. 230/kg, margin pemasaran Rp. $300 / \mathrm{kg}$. Saluran III pedagang pengecer mendapatkan keuntungan sebesar Rp. 520/kg, margin pemasaran Rp. 650/kg.
\end{abstract}

Kata Kunci: Usahatani Jagung Kuning dan Margin Pendapatan

\begin{abstract}
Zea mays ssp. mays farming in Gowa Regency, especially Bontolempangan Subdistrict, is a commodity that has the potential to be developed and can increase farmers' income. This study was directed to find out how Zea mays ssp. mays farming and its contribution to the income of farmers in Bontolempangan District, Gowa Regency. The income of Zea mays ssp. mays farmers is Rp. 5,061,919.00 per hectare per planting season, with an $R / C$ ratio of 3.69 and a $B / C$ ratio of 2.69, and the margin received for each marketing channel varies. For channel I, the collecting trader gets a profit of Rp. $90 / \mathrm{kg}$, marketing margin Rp. $150 / \mathrm{kg}$. Big traders get a profit of Rp. $130 / \mathrm{kg}$, marketing margin of Rp. $200 / \mathrm{kg}$. Retailers get a profit of Rp. $230 / \mathrm{kg}$, marketing margin of Rp. $300 / \mathrm{kg}$. For channel II, large traders get a profit of Rp. $255 / \mathrm{kg}$, marketing margin Rp. $350 / \mathrm{kg}$. Retailers get a profit of Rp. $230 / \mathrm{kg}$, marketing margin of Rp. $300 / \mathrm{kg}$. Channel III retailers get a profit of Rp. $520 / \mathrm{kg}$, marketing margin $R p .650 / \mathrm{kg}$
\end{abstract}

Keywords: Zea mays ssp. Mays farming and income margin

\section{PENDAHULUAN}

Kebijakan pembangunan pertanian yang ditujukan untuk meningkatkan ketahanan pangan mengembangkan agribisnis dan meningkatkan pendapatan petani, mengisyaratkan bahwa produk pertanian yang dihasilkan harus memenuhi syarat kuantitas, kualitas dan kontinuitas sehingga memiliki daya saing dan mudah diperoleh dengan harga yang terjangkau. Produksi komoditas tanaman pangan utama khususnya, jagung meskipun meningkat setiap tahunnya namun belum dapat memenuhi kebutuhan dalam negeri, terutama untuk bahan pakan ternak dan bahan baku industri lainnya, sehingga untuk mencukupinya masih mendatangkan (impor) dari negara lain.

Usahatani jagung kuning di Kabupaten Gowa khususnya Kecamatan Bontolempangan merupakan satu komoditi 
yang berpotensi untuk dikembangkan dan dapat meningkatkan pendapatan petani.

Peluang peningkatan produksi jagung dalam negeri masih terbuka lebar, baik melalui peningkatan produktivitas maupun perluasan areal tanaman. Area panen jagung di Indonesia saat ini baru sekitar 3,13 juta hektar. Sedangkan potensi lahan untuk pengembangan jagung tersedia cukup luas utamanaya pada lahan kering di luat jawa seperti Sumatera, Kalimantan, Sulawesi, Irian, dan Nusa Tenggara. Sekitar 6,96 juta hektar lahan yang terdapat di 14 propinsi tergolong berpotensi untuk pengembangan jagung (Dinas Tanaman Pangan dan Hortikultura, 2006). Apabila lahan itu dapat dimanfaatkan maka potensi areal tanam panen akan lebih besar karena sebagian lahan tersebut dapat ditanami jagung dua kali dalam setahun.

Penelitian ini diarahkan untuk mengetahui bagaimana usahatani jagung kuning dan konstribusinya terhadap pendapatan petani di Kecamatan Bontolempangan Kabupaten Gowa.

Sedangkan tujuan dalam penelitian ini untuk mengetahui besamya pendapatan yang diperoleh petani jagung kuning dan untuk untuk mengetahui besarnya margin dan keuntungan pada setiap level lembaga pemasaran jagung kuning di Kecamatan Bontolempangan Kabupaten Gowa.

\section{Tinjauan Pustaka}

\section{A. Sistem Budidaya Jagung Kuning}

Untuk memperoleh produktivitas yang tinggi, maka dalam penanaman jagung kuning perlu diperhatikan syarat pertumbuhan yang diinginkan oleh tanamanjagung maupun tehnik budidaya yang dilakukan. (AAK. 1993)

\section{Syarat tumbuh}

Syarat pertumbuhan sangat menentukan dalam pertumbuhan dan perkembangan tanaman jagung kuning sehingga produksi yang diharapkan dapat tercapai. Syarat tumbuh dari tanaman jagung kuning dilihat dari:

a. Keadaan iklim

Indonesia termasuk daerah tropis basah, tetapi keadaan iklim di wilayah nusantara amat bervariasi. Jumlah curah hujan di Indonesia antara 50-5000 mm per tahun. Distribusi curah hujan disebagian besar wilayah mempunyai bulan kering kurang dari 3 bulan, seperti dari daerah Jawa Tengah ke Timur sampai Nusa Tenggara Timur (NTT). Disamping itu keadaan suhu udara di Indonesia dipengaruhi oleh ketinggian tempat Indonesia terletak diantara lintang $6^{0} \mathrm{LU}-11^{0} \mathrm{LS}$ berpengaruh terhadap intensitas penyinaran matahari, terutama panjang dan pendeknya siang hari. Perbedaan panjang hari di Indonesia tidak mencolok yakni rata-rata mendekati $12 \mathrm{jam} / \mathrm{hari}$. Intensitas penyinaran matahari di Indonesia termasuk berhari pendek, disamping itu keadaan suhu udara di Indonesia dipengaruhi oleh keadaan tempat. Setiap naik 100 meter dari permukaan laut, suhu turun $1^{0} \mathrm{C}$. Dipermukaan laut, suhu rata-rata sekitar $28{ }^{0} \mathrm{C}$ dan di gunung yang berketinggian $2.000 \mathrm{~m}$ di atas permukaan laut (dpl). Tanaman jagung dapat beradaptasi luas terhadap lingkungan tumbuh secara umum, tanaman jagung kuning dapat tumbuh di dataran rendah sampai di atas ketinggian kurang lebih $1.300 \mathrm{~m}$ dpl. Selama pertumbuhan, tanaman jagung kuning membutuhkan suhu yang optimum antara $23^{\circ}-27^{\circ} \mathrm{C}$. meskipun keadaan suhu di Indonesia tidak merupakan masalah bagi pengembangan usahatani jagung kuning, tetapi panen pada musim kemarau lebih baik daripada panen pada musim hujan. Panen pada musim kemarau berpengaruh terhadap makin cepatnya kemasakan biji dan mempermudah proses pengeringan biji di bawah sinar matahari. Curah hujan 
yang ideal untuk tanaman jagung adalah 100-200 mm perbulan, curah hujan paling optimum adalah sekitar 100-125 mm per bulan dengan distribusi yang merata. Oleh karena itu, tanaman jagung kuning cenderung amat cocok ditanam di daerah yang berikim kering. Unsur iklim penting yang berpengaruh terhadap pertumbuhan dan produksi jagung kuning adalah faktor penyinaran matahari.

Tanamanjagung kuning membutuhkan penyinaran matahari penuh, maka tempat penanamannya harus terbuka. Di tempat yang terlindung (ternaungi) pertumbuhan batang tanaman jagung kuning menjadi kurus dan tongkolnya ringan sehingga produksinya cenderung menurun (rendah)

b. Keadaan Tanah

Tanah berdebu yang kaya hara dan humus amat cock untuk tanaman jagung kuning. Disamping itu, tanaman jagung kuning toleran terhadap jenis tanah, misalnya tanah andosol dan latosol, asalkan memiliki kesamaan tanah $(\mathrm{pH})$ yang memadai untuk tanaman tersebut. Tanah-tanah berpasir dapat ditanami jagung kuning dengan pengolahan air yang baik dan penambahan pupuk organik (pupuk kandang atau pupuk kompos). Demikian pula tanah-tanah berat misalnya tanah grumosal dapat ditanami jagung dengan pertumbuhan normal bila aerase dan drainase tanah diatur cukup baik. Tanah gambut dapat ditanami jagung kuning asalkan keasaman tanah $(\mathrm{pH})$ diperbaiki dengan cara pengapuran. Tanaman jagung kuning toleran terhadap reaksi keasaman tanah pada kisaran $\mathrm{pH}$ 5,5-7,0. tingkat keasaman tanah yang paling baik untuk tanaman jagung kuning adalah $\mathrm{pH}=6,8$

\section{Teknik Budidaya Jagung Kuning}

Warisno. (1998), Teknik budidaya sangat penting dilakukan dalam peningkatan hasil panen, baik kualitas maupun kuantitasnya. Pedoman teknis jagung kuning adalah sebagai berikut: a. Penyiapan benih

Benih bermutu tinggi yang berasal dari varietas unggul merupakan salah satu faktor penentuan untuk memperoleh kapasitas hasil usahatani jagung kuning. Benih jagung varietas bersari bebas kadang-kadang di produksi sendiri oleh petani. Hal yang penting diperhatikan dalam penyiapan benih jagung kuning hasil pembenihan sendiri, antara lain adalah pemilihan tongkol dan biji yang dijadikan benih. Tongkol berumur tua, ukurannya besar dan kelobatnya menutup rata; dan (2) bentuk tongkol bulat panjang (silindris), barisan biji pada tongkol lurus dan berwarna biji seragam.

Kebutuhan benih jagung kuning persatuan luas lahan dipengaruhi oleh faktor jarak tanam, jumlah benih per lubang tanam, keadaan lahan yang mampu untuk ditanami, berat benih, dan daya kecambah benih. Jumlah benih jagung kuning yang diperlukan berkisar antara 20-40 kg per hektar.

b. Penyiapan lahan

Penyiapan lahan untuk tanaman jagung kuning dapat dilakukan dengan tiga cara yaitu : tanpa olahan tanah (TOT) atau disebut zero tiliage, pengolahan tanah minimum (minimum tillage), dan pengolahan tanah maksimum (maximum tillage).

Tujuan pengolahan tanah secara sempurna adalah sebagai berikut:

1) Memperbaiki tekstur dan struktur tanah

2) Memberantas gulma dan hama dalam tanah

3) Memperbaiki aerase dan drainase tanah

4) Mendorong aktivitas mikroorganisme tanah

5) Membuang gas-gas beracun dari dalam tanah

c. Penanaman

Penanaman jagung kuning pada umumnya dilakukan pada musim kering atau disebut jagung merengan. Meskipun 
penanaman jagung kuning kadangkadang dilakukan pada musim hujan yang disebut jagung labuhan. Jagung yang ditanam pada musim hujan mengalami banyak hambatan, antara lain: terlalu jenuh air, risiko serangan penyakit cukup tinggi, proses pengolahan pascapanen terganggu dan produksinya menurun. Tata cara penanaman benih jagung kuning secara monokultur (satu jenis) yaitu meliputi tahapan-tahapan:

1. Buat lubang tanah dengan menggunakan alat bantu tugal sedalam $2-5 \mathrm{~cm}$

2. Atur lubang tanaman yang lain dengan jarak tanam $100 \mathrm{~cm}$ x 40 $\mathrm{cm}$ atau $100 \mathrm{~cm} \times 25 \mathrm{~cm}$

3. Tanamkan (masukkan) benih jagung kuning sebanyak 2 butir per lubang dengan jarak tanam $100 \mathrm{~cm} \mathrm{x} 40 \mathrm{~cm}$ dengan 1 butir per lubang bila jarak tanam 100 $\mathrm{cm} \times 25 \mathrm{~cm}$

4. Tutup lubang tanaman dengan tanah tipis dipadatkan.

\section{d. Pemupukan}

Dosis pupuk yang dibutuhkan oleh tanaman jagung kuning adalah pupuk Urea $300 \mathrm{~kg}$; TSP $100 \mathrm{~kg}$; dan KCL 50$100 \mathrm{~kg}$ per hektar. Jumlah pupuk tersebut diberikan sebanyak tiga kali.

e. Pemeliharaan Tanaman

Pemeliharaan tanaman meliputi penyulaman atau penjarangan, penyiangan dan pemberantasan hama dan penyakit. Penyulaman dilakukan setelah 15 hari setelah tanam. Penyiangan dilakukan 2 kali yaitu pada saat berumur 15 hari setelah tanam. Pemberantasan hama dan penyakit sebaiknya dilakukan apabila ada gejala hama dan penyakit yang menyerang tanaman. Tetapi dapat pula diantisipasi dengan jalan penyemprotan dilakukan pada waktu yang berbeda tergantung jenis hama penyakit dan pola penyerangannya.

\section{f. Panen dan pascapanen}

Penentuan saat panen jagung kuning yang paling tepat amat tergantung pada tujuan penggunaan produksi. Untuk dikonsumsi sebagai jagung rebus atau jagung bakar, saat panen yang paling tepat adalah stadium tongkol setengah tua yakni tongkol berukuran maksimum, berbiji penuh, padat dan bila biji ditekan tampak keras melekuk. Pada skala usaha komersial, panen tongkol jagung umumnya dilakukan setelah mencapai stadium tua (matang fisiologis), karena biji-bijinya akan dikeringkan.

Rukmana, R. (1997) menyebutkan ciri-ciri tongkol jagung kuning siap dipanen pada stadium matang fisiologis adalah sebagai berikut;

1. Tongkol berumur 7-8 minggu setelah keluar bunga

2. Kelobot tongkol sudah berwarna kuning

3. Bila tongkol dikupas akan tampak biji jagung berwarna kuning, putih atau kemerah-merahan (sesuai dengan karakter varietas) dan penampilannya mengkilap.

4. Bila biji ditekan dengan tidak meninggalkan bekas lekukan.

5. Kadar air dalam biji sudah mencapai 35-40\%

Pascapanen dilakukan melalui beberapa tahapan yaitu: (1) pengumpulan hasil; (2) pewadahan; (3) pengangkutan; (4) pengeringan tongkol; (5) pemipilan; dan (6) penyimpanan biji jagung di tempat yang kering dan bersih, (Purwono dan Hartono, 2005)

\section{B. Konsep Pendapatan}

MenurutSoekartawi(1995), pendapatan usahatani adalah selisih antara penerimaan dan semua biaya, hal ini dapat dihitung dengan persamaan :

$$
\pi=\mathrm{TR}-\mathrm{TC}
$$

$$
\begin{array}{rll}
\text { Dimana: } \pi & = & \text { pendapatan } \\
\text { TR } & = & \text { Total Revenue } \\
\text { TC } & = & \text { Total Cost }
\end{array}
$$


Lebih lanjut Soekartawi (1995) menjelaskan bahwa penerimaan usahatani adalah merupakan perkalian antara produksi yang diperoleh dengan harga jual. Secara matematik pernyataan tersebut dapat dituliskan sebagai berikut:

$$
\mathrm{TR}=\text { YX Py }
$$

Dimana: $\mathrm{TR}=$ Total Penerimaan

$$
\mathrm{Y}=\begin{gathered}
\text { Jumlah Produksi yang } \\
\text { Dihasilkan }
\end{gathered}
$$$$
\text { Py = Harga Jual Produksi }
$$

Biaya usahatani diklasifikasikan menjadi dua bagian yaitu biaya tetap (fixed cost) dan biaya tidak tetap (variabel cost), sedangkan total biaya (TC) adalah jumlah dari biaya tetap dan biaya tidak tetap, maka total biaya (TC) dituliskan dengan persamaan sebagai berikut;

$$
\mathrm{TC}=\mathrm{FC}+\mathrm{VC}
$$

Selanjutnya Soekartiwi (2001) mendefinisikan pendapatan sebagai selisih antarapenerimaan dengan semua biaya yang dikeluarkan selama melakukan usahanya, dengan kata lain penerimaan dikurangi biaya produksi maka hasilnya adalah pendapatan. Dalam menganalisa pendapatan ada beberapa pengertian yang perlu diperhatikan yaitu :

a. Penerimaan kotor (gross farm income) usahatani yaitu nilai produk total usahatani dalam jangka waktu tertentu. biasanya usahatani menerima antara lain baik yang tidak dijual maupun yang dijual, misalnya uang tunai dari hasil penjualan produknya, kredit dari hasil penjualan, dan total penerimaan modal akhir tahun.

b. Biaya produksi adalah semua pengeluaran yang dinilai dengan uang yang diperlukan untuk menghasilkan produksi. Biaya produksi antara lain yakni harga bahan baku, upah tenaga kerja, biaya operasional dan lain-lain. c. Pendapatan bersih (net farm income) diartikan sebagai penerimaan kotor dikurangi dengan biaya produksi atau penerimaan kotor dikurangi dengan biaya tetap dan biaya variabel lainnya.

d. Penghasilan bersih usahatani (net earning farm) yaitu pendapatan bersih usahatani dikurangi bunga modal pinjaman.

Soehardjo dan Patong (1987) pendapatan adalah selisih antara nilai produksi dengan jumlah biaya yang dikeluarkan. Pendapatan kotor usahatani dalam jangka waktu tertentu merupakan nilai produksi total usahatani. Jadi pendapatan kotor adalah semua pendapatan yang diperoleh dalam proses produksi dengan menghitung pengeluaran yang diberikan waktu pengolahan lahan pertanian.

Hernanto (1988), mengemukakan bahwa beberapa faktor yang mempengaruhi pendapatan usahatani yaitu (1) luas lahan yang meliputi areal tanam, luas pertanaman dan luas pertanaman ratarata; (2) tingkat produksi yang diukur dari produktivitas per hektar dari indeks pertanaman; (3) pemilihan dan kombinasi cabang usahatani; (4) intensitas penguasaan lahan; dan (5) efesiensi tenaga kerja.

Adiwilaga (1982) mengemukakan bahwa keuntungan petani adalah selisih antara kenaikan nilai antara kekayaan pada awal kegiatan usahatani dengan nilai akhir kegiatan usahatani yang bersangkutan. Dengan kata lain bahwa pendapatan petani adalah selisih antara hasil penjualan panen dengan biaya usahatani.

\section{METODE ANALISIS DATA}

Analisis data dilakukan dengan menggunakan analisis pendapatan untuk mengetahui pendapatan yang diperoleh petani. Kemudian dilanjutkan dengan analisis $\mathrm{R} / \mathrm{C}$-ratio dan $\mathrm{BC}$ ratio,, untuk 
mengetahui margin keuntungan dan efesiensi pemasaran digunakan analisis margin pemasaran dan keuntungan kemudian dilanjutkan analisis efesiensi pemasaan.

\section{PEMBAHASAN}

\section{Analisis Biaya dan Pendapatan}

Analisis biaya dan pendapatan merupakan suatu analisis yang memperlihatkan penerimaan dan pengeluaran yang terjadi selama periode bersangkutan.

Analisis usahatani biaya per hektar ditujukan agar petani lebih mudah memahami besarnya modal yang dikeluarkan dan perkiraan keuntungan yang akan diperoleh.

Pada dasarnya biaya-biaya yang dikeluarkan dalam proses produksi terdiri atas Biaya Tetap (Fixed Cost) dan Biaya Variabel (Variable Cost). Biaya tetap adalah biaya yang sifatnya tidak dipengaruhi oleh besarnya produksi. Sedangkan biaya variabel adalah biaya yang sifatnya bisa berubah-ubah sesuai dengan besarnya produksi.

Biaya tetap yang dikeluarkan selama proses produksi jagung kuning adalah biaya Pajak Bumi dan Bangunan. Sedangkan biaya variabel meliputi pembelian bibit, pupuk, obat-obatan dan biaya tenaga kerja. Tabel berikut ini akan merinci biaya-biaya dan keuntungan rata-rata usahatani jagung kuning dalam skala usaha 1 hektar selama satu periode tanam, dengan asumsi status lahan milik sendiri.

Tabel 1.Analisis Biaya dan Pendapatan Rata-rata Usahatani Jagung Kuning di Kecamatan Bontolempangan, 2008.

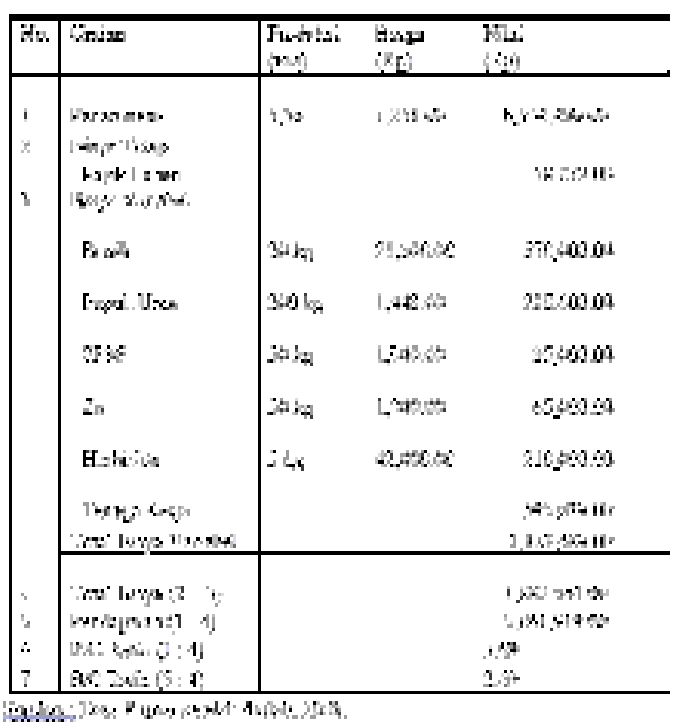

Analisis di atas menunjukkan bahwa rata-rata penerimaan sebesar Rp. 6.944.480,00 per musim tanam per hektar. Total biaya (biaya tetap + biaya variabel) sebesar Rp. 1.823.689,00 keuntungan sebesar Rp. 5.061.919,00 dengan $\mathrm{R} / \mathrm{C}$ ratio 3,69 dan $\mathrm{B} / \mathrm{C}$ ratio 2,69 .

Dari hasil analisis sepintas berarti menguntungkan, tetapi keuntungan yang diperoleh petani tergolong rendah, karena proses budidaya jagung kuning memakan waktu yang cukup lama $( \pm 6$ bulan). Selain itu keuntungan harus disisihkan petani untuk pembelian sarana produksi (saprodi) untuk budidaya berikutnya. Jika status lahan yang diusahakan petani adalah lahan garapan, maka keuntungan petani tersebut akan terbagi kepada pemilik lahan. Terdapat dua pola pembagian hasil antara petani dan pemilik lahan yaitu (1) jika sebagian biaya produksi ditanggung oleh pemilik lahan, maka petani mendapat seperdua atau setengah bagian dari hasil penerimaan jagung 
kuning, (2) jika biaya produksi ditanggung oleh petani, maka pemilik lahan sepertiga bagian dari hasil penerimaan jagung kuning. Maka keuntungan tersebut tentu saja jauh dari kecukupan petani untuk menghidupi diri dan keluarganya selama menunggu musim panen berikutnya.

\section{Margin Biaya dan Keuntungan}

Margin pemasaran jagung kuning adalah selisih antara harga penjualan dengan harga pembelian jagung kuning oleh lembaga pemasaran. Biaya pemasaran jagung kuning adalah biaya yang dikeluarkan oleh lembaga pemasaran dalam memasarkan jagung kuning tersebut meliputi biaya transportasi, biaya penyimpanan, biaya sortosi atau grading, retribusi, pengemasan, bongkar muat, dan penimbangan.. Keuntungan pemasaran jagung kuning adalah selisih antara margin pemasaran dengan biaya pemasaran jagung kuning.

Analisis margin biaya dan keuntungan bertujuan untuk memberikan gambaran berapa besar keuntungan yang diperoleh petani responden dan rantai pemasaran berikutnya.

Untuk lebih jelasnya mengenai besarnya margin, biaya dan keuntungan jagung kuning pada masing-masing lembaga yang terlibat dalam mendistribusikan jagung kuning dari petani responden sebagai berikut :

\section{a. Margin, Biaya dan Keuntungan Masing-masing Lembaga Pemasaran pada Saluran I.}

Lembaga pemasaran yang terlibat pada saluran 1 terdiri dari pedagang pengumpul, pedagang besar dan pedagang pengecer. Untuk lebih jelasnya mengenai margin, biaya dan keuntungan pada saluran 1 dapat dilihat pada tabel di bawah ini.

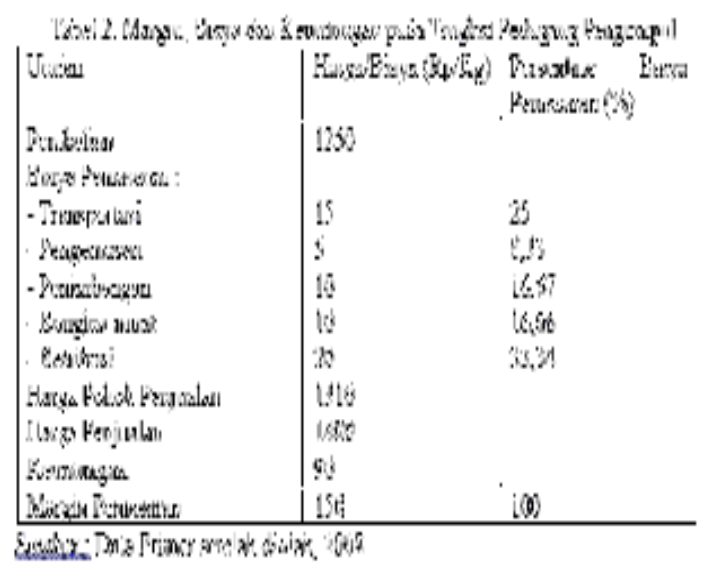

Hasil penelitian menunjukkan bahwa kegiatan yang dilakukan pedagang pengumpul yang membeli langsung ke petani dimana jagung yang dibeli telah dilakukan perlakuan penimbangan, pengemasan transportasi, bongkar muat. Kemudian harga pembelian jagung sebagian ditentukan oleh pedagang jagung dan sebagian lagi ditentukan berdasarkan tawar menawar antara pedagang pengumpul dan petani. Biaya pemasaran yang dikeluarkan sebesar Rp. 60 perkilogram dan keuntungan yang diperoleh sebesar Rp. 90 perkilogram dan margin pemasaran sebesar Rp. 150 perkilogram.

Margin pemasaran pada tingkat pedagang besar dapat dilihat pada tabel di bawah ini :

\begin{tabular}{|c|c|c|}
\hline Uraiann & $\begin{array}{l}\text { Harga Biaya } \\
(\mathrm{Rp} \mathrm{Kg})\end{array}$ & \begin{tabular}{|l|} 
Persentase Biaya \\
Pemasaran $(\%)$ \\
\end{tabular} \\
\hline $\begin{array}{l}\text { Pembelian } \\
\text { Biaya Pemasaran: }\end{array}$ & 1400 & \\
\hline - Transportasi & 35 & 50 \\
\hline - Bongkar muat & 15 & 21,43 \\
\hline - Retribusi & 20 & 28,57 \\
\hline Harga Pokok Penjualan & 1470 & \\
\hline Harga Penjualan & 1600 & \\
\hline Keuntungan & 130 & \\
\hline Margin Pemasaran & 200 & 100 \\
\hline
\end{tabular}

Sumber: Data Primer setelah diolah, 2008 
Hasil penelitian menunjukkan kegiatan yang dilakukan oleh pedagang besar yaitu membeli dari pedagang pengumpul dengan harga Rp. 1400. Biaya pemasaran yang dikeluarkan sebesar 70 perkilogram, keuntungan yang diperoleh Rp. 130 perkilogram dan margin pemasaran Rp. 200 perkilogram. Margin pemasaran pada tingkat pengecer dapat dilihat pada tabel di bawah ini :

\begin{tabular}{|c|c|c|}
\hline Uraian & $\begin{array}{l}\text { Harga Biaya } \\
(\mathrm{Rp} \mathrm{Kg})\end{array}$ & $\begin{array}{l}\text { Persentase Biaya } \\
\text { Pemasaran }(\%)\end{array}$ \\
\hline \begin{tabular}{|l} 
Pembelian \\
Biaya Pemasaran: \\
- Transportasi \\
- Retribusi \\
Harga Pokok Peniualan \\
Harga Penjualan \\
Keuntungan \\
\end{tabular} & $\begin{array}{l}1600 \\
45 \\
25 \\
1670 \\
1900 \\
230 \\
\end{array}$ & $\begin{array}{l}64,29 \\
35,71\end{array}$ \\
\hline Margin Pemasaran & 300 & 100 \\
\hline
\end{tabular}

Tabel 4 menunjukkan bahwa kegiatan yang dilakukan oleh pedagang pengecer kota Makassar yaitu membeli di Kabupaten Gowa dan menjualnya ke konsumen akhir kota Makassar.

Biaya pemasaran yang dikeluarkan sebesar Rp. 20 perkilogram dan keuntungan Rp. 230 perkilogram serta margin pemasaran Rp. 300 perkilogram.

Dari ketiga lembaga pemasaran yang terdapat pada saluran pemasaran 1 maka pedagang pengecer yang memiliki tingkat margin paling tinggi yaitu $\mathrm{Rp}$. 300 perkilogram karena langsung ke konsumen akhir.

b. Margin, Biaya dan Keuntungan masingmasing Lembaga Pemasaran Saluran II

Lembaga pemasaran yang terlibat pada saluran II terdiri dari pedagang besar dan pedagang pengecer. Untuk lebih jelasnya mengenai besarnya margin, biaya dan keuntungan pemasaran pada masing-masing lembaga yang terlibat dalam mendistribusikan jagung di bawah ini :

Tabel 5. Analisis. Margin, Biaya dan Keuntungan pada Tingkat Peddganng Besar

\begin{tabular}{|l|l|l|}
\hline Uraian & Harga Biaya (Rp/Kg) & $\begin{array}{l}\text { Persentase Biaya } \\
\text { Pemasaran (\%) }\end{array}$ \\
\hline Pembelian & 1250 & \\
Biaya Pemasaran: & & \\
- Transportasi & 35 & 36,84 \\
- Pengemasan & 15 & 15,79 \\
-Penimbangan & 20 & 21,05 \\
- Bongkar muat & 10 & 10,53 \\
- Retribusi & 15 & 15,79 \\
Harga Pokok Penjualan & 1345 & \\
Harga Penjualan & 1600 & \\
Keuntungan & 255 & 100 \\
\hline Margin Pemasaran & 350 & \\
Sumber : Data Primer setelah diolah, 2008 &
\end{tabular}

Hasil penelitian menunjukkan kegiatan yan dilakukan oleh pedagang besar yaitu membeli dari pedagang pengumpul di Kecamatan Bontolempangan. Biaya pemasaran yang dikeluarkan sebesar Rp. 95 perkilogram, keuntungan yang diperoleh sebesar Rp. 255 perkilogram dan margin pemasaran Rp. 350 perkilogram.

Margin, biaya, dan keuntungan pemasaran pada tingkat pedagang pengecer dapat dilihat pada tabel di bawah ini :

Tabel 6. Margin, Biaya dan Keuntungan pada Tingkat Pedagang Pengecer

\begin{tabular}{|c|c|c|}
\hline Uraian & $\begin{array}{l}\text { Harga Biaya } \\
(\mathrm{Rp} \mathrm{Kg})\end{array}$ & $\begin{array}{l}\text { Persentase Biaya } \\
\text { Pemasaran }(\%)\end{array}$ \\
\hline \begin{tabular}{|l|} 
Pembelian \\
Biaya Pemasaran: \\
- Transportasi \\
- Retribusi \\
Harga Pokok Penjualan \\
Harga Penjualan \\
Keuntungan \\
\end{tabular} & $\begin{array}{l}1600 \\
45 \\
45 \\
1670 \\
1900 \\
230\end{array}$ & $\begin{array}{l}64,28 \\
35,71\end{array}$ \\
\hline Margin Pemasaran & 300 & 100 \\
\hline
\end{tabular}

Sumber: Data Primer setelah diolah, 2008

Hasil penelitian menunjukkan bahwa kegiatan yang dilakukan oleh pedagang 
pengecer kota Makassar yaitu membeli di Kecamatan Bontolempangan dan Kabupaten Gowa dan menjualnya ke konsumen akhirdi Kota Makassar. Biaya pemasaran yang dikeluarkan sebesar Rp. 70 perkilogram dan keuntungan Rp. 230 perkilogram serta margin pemasaran Rp. 300 perkilogram.

Dari ketiga lembaga pemasaran yang terdapat pada saluran distribusi II maka pedagang besar yang memiliki tingkat margin paling tinggi yaitu $\mathrm{Rp}$. 350 perkilogram karena langsung ke konsumen akhir.

\section{c. Margin, Biaya dan Keuntungan Masing-masing Lembaga Pemasaran Saluran III}

Lembaga pemasaran yang terlibat pada saluran III terdiri dari pedagang pengecer. Untuk lebih jelasnya mengenai besar margin, biaya dan keuntungan pemasaran pada masingmasing lembaga pemasaran yang terlibat dalam mendistribusikan jagung dapat dilihat pada tabel di bawah ini :

\begin{tabular}{|c|c|c|}
\hline Uraian & Harga Biaya (Rp/Kg) & $\begin{array}{l}\text { Persentase Biaya } \\
\text { Pemasaran }(\%) \\
\end{array}$ \\
\hline \begin{tabular}{|l} 
Pembelian \\
Biaya Pemasaran: \\
- Transpportasi \\
- Pengemasan \\
- Penimbangan \\
- Bongkar muat \\
- Retribusi \\
Harga Pokok Penjualan \\
Harga Penjualan \\
Keuntungan \\
\end{tabular} & $\begin{array}{l}1250 \\
40 \\
15 \\
35 \\
15 \\
25 \\
1380 \\
1900 \\
420 \\
\end{array}$ & $\begin{array}{l}30,77 \\
11,54 \\
26,92 \\
11,54 \\
19,23\end{array}$ \\
\hline Margin Pemasaran & 650 & 100 \\
\hline
\end{tabular}

Sumber: Data Primer setelah diolah, 2008

Hasil penelitian menunjukkan bahwa kegiatan yang dilakukan para pedagang pengecer adalah membeli langsung ke petani, kemudian menjualnya ke konsumen. Biaya pemasaran yang dilakukan adalah biaya transportasi, biaya bongkar muat, retribusi, pengemasan, dan penimbangan yang totalnya mencapai Rp. 130 perkilogram dengan margin pemasaran yang diperoleh sebesar 650 perkilogram.

\section{KESIMPULAN}

Pendapatan petani jagung kuning sebesar Rp. 5.061.919,00 per hektar per musim tanam, dengan $\mathrm{R} / \mathrm{C}$ ratio sebesar 3,69 dan $\mathrm{B} / \mathrm{C}$ ratio 2,69 , dan margin yang diterima tiap-tiap saluran pemasaran berbeda-beda. Untuk saluran I pedagang pengumpul mendapatkan keuntungan sebesar Rp. 90/kg, margin pemasaran Rp. 150/kg. Pedagang besar mendapatkan keuntungan sebesar Rp. 130/kg, margin pemasaran Rp. 200/kg. Pedagang pengecer mendapatkan keuntungan sebesar Rp. 230/kg, margin pemasaran Rp. 300/kg. Untuk saluran II pedagang besar mendapatkan keuntungan sebesar Rp. 255/kg, margin pemasaran Rp. $350 / \mathrm{kg}$. Pedagang pengecer mendapatkan keuntungan sebesar Rp. 230/kg, margin pemasaran Rp. 300/kg. Saluran III pedagang pengecer mendapatkan keuntungan sebesar Rp. 520/kg, margin pemasaran Rp. 650/kg.

Sedangkan pemerintah dalam hal ini penentu keputusan dan kebijaksanaan harga seyogyanya lebih proaktif dalam menangani harga jagung di petani yang masih rendah. Perlu ditempuh kebijakan penetapan harga dasar yang berorientsi pada petani sebagai produsen untuk meningkatkan pendapatan petani. Kemudian upaya peningkatan pendapatan petani khususnya petani jagung kuning memerlukan peran pemerintah dalam intensitas yang lebih besar lagi. Peran tersebut dibutuhkan dalam berbagai faktor antara lain ; penguatan kelembagaan, pemberdayaan kelompok tani, pemberdayaan lembaga permodalan, penguatan fungsi fasilitator dan mediator untuk jalur kemitraan antara petani dan swasta yang saling menguntungkan. 
DAFTAR PUSTAKA

Dinas Tanaman Pangan dan Hortikultura, 2006. Laporan Tahunan Kabupaten Gowa. Dinas Tanaman Pangan dan Hortikultura Kabupaten Gowa.

AAK. 1993. Tehnik Bercocok Tanam Jagung. Kanisius, Yogyakarta.

Warisno. 1998. Budidaya Jagung Hibrida. Kanisius, Yogyakarta.

Purwono dan Hartono, 2005. Bertanam Jagung Unggul. Penebar Swadaya, Jakarta.

Rukmana, R. 1997. Usaha Tani Jagung. Kanisus Yogyakarta.
Soekartawi.1995. Analisis Usaha Tani. UIPress, Jakarta.

Soekartawi. 2001. Prinsip Dasar Manajemen Pemasaran. Hasil-Hasil Pertanian (Teori dan Aplikasinya). Cetakan Ketiga. PT. Raja Grafindo Persada, Jakarta.

Soehardjo dan Patong. 1987. SendiSendi Pokok Ilmu Usaha Tani. LEPHAS, Ujung Pandang.

Hernanto, F. 1988. Ilmu Usaha Tani. PT. Penebar Swadaya, Jakarta.

Adiwilaga. 1982. Ilmu Usahatani. Alumni, Bandung. 